\title{
LIPID CONTENT OF SOME GREEN ALGAE FOR BIODIESEL
}

\author{
Lalita L. Sawarkar* and Shaligram R. Hiwale
}

K.Z.S.Science College Bramhani-Kalmeshwar, (Maharashtra). India 441501

Email Id: 1sawerkar5@gmail.com

Revision : 05.01.2020

Accepted : 25.01.2020

Published: 30.01 .2020

\begin{abstract}
:
With increasing fuel prices, Its transportation and environmental concerns, each country will have to think to cut down on petroleum based fuels while investing and researching on various renewable energy sources. An attempt is made to examine lipid content of green algae for production of biodiesel. Some of the green algae of Nagpur region have been taken into account to evaluate the lipid content as biodiesel. Among the green algae members of zygnemaceae may show encouraging result if it contain above $8 \%$ lipid per gram of dry biomass.
\end{abstract}

Key words: - Biodiesel, green algae and zygnemaceae.

\section{INTRODUCTION:}

Worldwide concerns over global climate change, national energy security, rising fuel costs and the diminishing supply of inexpensive fossil fuels have stimulated an interest on renewable energy resources. Currently, there are few renewable energy resources that can compete directly with petroleum, especially in the transportation sector. Biofuels, such as bioethanol and biodiesel are emerging as a competitive alternative to petrofuel due to their renewable source, superior environmental benefits if it could be able to produce in sufficient quantities with a positive net energy gain. All factors may be critical to long-term substitution of fossil fuels(10).

Bioenergy is one of the most important components to mitigate greenhouse gas emission and substitute of fossil fuels (3).The energy need as on today is continuously increasing due to , industrialization and growing population. The basic sources of this energy are petroleum, natural gas ,coal, hydro and nuclear power(3).

Fossil fuels have been the principal resource of energy for steering infrastructural and economic developments both in the developing and the developed world(2).There has however been a depletion in fossil fuel reserves fuel prices resulting in unequal availability of these resources between developing and developed nations of the world(2).Total dependence on fossil fuels for energy requirements is no longer sustainable and hence in the last few decades, research has been intensified for developing new renewable resources of energy(2).

One major competitor in the new alternative sources of energy to fossil fuels is biodiesel. There is opportunity to make a major impact and fill an important niche in the petroleum industry by utilizing renewable resources to produce transportation fuels. The majority of the renewable fuel used is produced from biomass. Biomass usually consists of plant material or agricultural wastes and for transportation purposes, would likely be converted into ethanol or a form of biodiesel. It is likely to produce ethanol or biodiesel for the purpose of transportation from biomass.

Biodiesel is an especially interesting substitute for petroleum due to positive net energy ratio. 
Also, B100 (100 per cent biodiesel with no petrodiesel to supplement the mixture) can be utilized as a direct petroleum substitute without major changes to the current infrastructure (engines, storage and distribution). Biodiesel comprises methyl esters produced by the Transesterification of biomass oils with an alcohol (usually methanol or ethanol).Greater than 350 biomass resources have been identified as a triglyceride source for the production of biodiesel. Table 1 identifies the most commonly investigated feedstock. Rapeseed, oil palm, soybean and sunflower are the primary feedstock's utilized for the production of biodiesel (10).

Microalgae are sunlight driven cell factories that convert carbon dioxide to potential Biofuels ,foods, feeds and high-value bioactive (4).In addition, these photosynthetic microorganisms are useful in bioremediation applications and as nitrogen fixing biofertilizer(4).

Microalgae unicellular photosynthetic organisms are particularly attractive as a feedstock as they will not displace agricultural crops, can be grown, harvested continuously throughout the year. Algae as a feedstock, they have a high growth rate, ability to thrive in saline water, capability of sequestering carbon dioxide $\left(\mathrm{CO}_{2}\right)$, use of nutrients (such as nitrogen and phosphorous) from waste products (such as sewage). In spite of oil content 20-50 percent( dry weight) in algae is in the range, some strains are adding up to 80 percent of dry weight basis. Algae are capable of doubling their biomass in a 24-hour that period can produce 8 - 24 times the triglycerides per area as other biomass resources, enabling the production 58,700 - 136900 liter oil h / year. It is estimated that between 2 and 6 per cent of the total US cropping area would be sufficient to produce enough algal oil for biodiesel production to entirely satisfy its transportation fuel needs (10).

\section{MATERIAL AND METHODS:-}

\subsection{Materials}

Sample collection: The fresh water green algae Rizoclonium sp., Cladophora sp., Zygnema sp., Spirogyra sps. were collected from water bodies of Nagpur and nearby Nagpur region. All the materials were washed with water and dried in sunlight for a few days. Dried algae were crushed in order to obtain small solid particles.

\subsection{Oil Extraction}

$200 \mathrm{ml}$ petroleum ether for 15-20 g of dried algae were used for the oil extraction. The extraction was carried out in Soxhlet apparatus for at least 12-16 $\mathrm{h}$ and recorded algal oil content.

Extraction was carried out in a $0.5 \mathrm{~L}$ round bottomed glass flask. The resultant solution was separated from solvent by distillation. The same solvent was reused in the next batch of extraction. Finally, the sample was dried in an oven $\left(100^{\circ} \mathrm{C}\right)$ to get constant weight of oil (6).

\subsection{Oil content}

Oil percent of algae (per gram of dry mass) = weight by difference in algae / original weight of

\section{Algae X 100}

\section{RESULT AND DISCUSSION}

The first step of this study is to characterize the material suitable for Transesterification process. The second step is to find suitability of biodiesel with fossil fuel (Diesel)

\subsection{Algal characterization:}

Seven types of algae were collected from water bodies of Nagpur and nearby Nagpur and analyzed to record the oil content from extraction of green algae. Oil contents recorded in the range of $1 \%$ to $8.3 \%$ per gm of dry mass. 


\begin{tabular}{|l|l|}
\hline \multicolumn{1}{|c|}{ Samples } & \multicolumn{1}{c|}{$\begin{array}{c}\text { ofil content (per gram } \\
\text { of dry mass) }\end{array}$} \\
\hline 1 Rizoclonium $\mathrm{sp}$. & $1-2$ \\
\hline 2 Cladophora $\mathrm{sp}$. & $3-3.5$ \\
\hline 3 Zygnema $\mathrm{sp}$ & 8.3 \\
\hline 4 Spirogyra $\mathrm{Sp}$ & 7.2 \\
\hline 5 Spirogyra $\mathrm{Sp}$ & 4.3 \\
\hline 6 Spirogyra $\mathrm{Sp}$ & 4.1 \\
\hline 7 Spirogyra $\mathrm{Sp}$ & 4.0 \\
\hline
\end{tabular}

\section{CONCLUSION}

Biodiesel has great potential; however the high cost and limited supply of organic oils prevent it from becoming competitor for petroleum fuels. In considering, the present petroleum fuel costs, it's supply and scarcity, an alternative fuels biodiesel may attract an attention to future demand of fuel by producing high oil content in algal biomass. Using new and innovative techniques for cultivation, algae may allow biodiesel production to achieve the price and scale of production needed to compete with petroleum.

\section{REFERENCES:}

A.B.M. Sharif Houssain et al., (2008)."Biodiesel Fuel Production from Algae as Renewable Energy." American journal of biochemistry and biotechnology 4(3): 250-254.

Arjun B. Chhetri et al.(2008) "Non-Edible Plant Oils as New Sources for Biodiesel Production. International Journal of Molecular Sciences 9, 169-180.

Ayhan Demirbas (2008) "Biodiesel: A Realistic fuel Alternative for Diesel Engines". B" on plant species studies
G. S.Venkataraman (1969) "The cultivation of Algae (The book on Algae)". Indian Counsil of Agricultural research.

http://journeyto forever.org/biodiesel-yield.html

L. Govindarajan et al. (2009). "Novel solvent extraction for extraction of oil from algae biomass grown in desalination regect stream". Journal of algal biomass utilization. 1(1):18-28.

Matthu N. Campbell (2008). "Biodiesel: Algal as a Renewable Source for liquid Fuel". Guelph Engineering Journal, (1) 2-7

Rashmi Kumari et al. (2012). Biodiesel production from seed of Cleome viscose L. Indian Journal of Experimental Biology. 50:502-510

Yusuf Chisti (2007). Biodiesel from Microalgae. Science Direct 25:294-306

Preiss and Kowalski (2010). "A summary of representative patents and patent applications in the algal biodiesel technology space and their commercial applications." Journal of Commercial Biotechnology 16, 293 - 312.

Sonia Heaven et al.(2011). 'Anaerobic digestion of microalgae as a necessary step to make microalgae biodiesel sustainable' Biotechnology Advances 29:164-167

Jasvinder Singh et al. (2010). "Commercialization potential of microalgae for Biofuels production" Renewable and Sustainable Energy Reviews,(14). 2596-2610 